\title{
Multiplex PCR Method of Detecting Pork to Guarantee Halal Status in Meat Processed Products
}

\author{
M. Indriati ${ }^{1} \&$ E. Yuniarsih ${ }^{1}$ \\ ${ }^{1}$ Universitas Mathla'ul Anwar Banten \\ Jl Raya Labuan Km 23 Cikaliung Saketi Kabupaten Pandeglang Banten \\ Email koresponden author: marlindaindriati87@gmail.com
}

\begin{abstract}
One of the halal parameters of food is must be free from pork among from the basic ingredients, additives and the manufacturing process. The aim of this study was ensure the halal status in the form of presence or absence of pork in processed meat product (meatballs and sausages) in traditional markets in Pandeglang Regency. PCR multiplex was a PCR technique that used several primers together in one reaction to amplify several target sequence. The genes often used as markers of animal or meat types include cytochrome b (cyt b), the existence of sequence variations in cyt b causes these genes are widely used as markers to distinguish material from different types of animals. The results showed that the cyt b gene proved successful in amplified DNA from beef and pork with different fragment lengths in the DNA mix of the 2 types of livestock in one reaction so that 2 DNA bands formed with different lengths according to the length of the fragment from each animal. From the results of research showed beef and pork control there was two fragments such as $274 \mathrm{bp}$ for beef and $389 \mathrm{bp}$ for pork. Multiplex PCR testing on meatball samples showed that the meatballs were tested $100 \%$ positive containing beef and $0 \%$ containing pork DNA. While testing on sausage products, there were one sausage brand that showed the results of DNA amplification of 398pb, which means the product was positive containing pork.
\end{abstract}

Keywords: Meatball, cyt b, DNA, PCR, sausage

\begin{abstract}
ABSTRAK
Salah satu parameter status halal bahan pangan tersebut harus bebas dari kandungan babi baik dari bahan dasar, bahan tambahan maupun proses pembuatannya. Tujuan dari penelitian ini adalah memastikan status kehalalan berupa ada tidaknya kandungan babi pada bahan pangan olahan daging (bakso dan sosis) yang beredar di pasar tradisional di wilayah Kabupaten Pandeglang. Multipleks PCR adalah suatu teknik PCR dengan menggunakan beberapa primer secara bersama-sama dalam satu reaksi untuk amplifikasi beberapa daerah target. Gen-gen yang paling sering digunakan sebagai penanda jenis hewan atau daging diantaranya adalah cytochrome $b$ (cyt $b$ ), adanya variasi urutan pada cyt b menyebabkan gen ini banyak digunakan sebagai penanda untuk membedakan material yang berasal dari jenis hewan yang berbeda. Hasil penelitian menunjukan bahwa gen cyt b terbukti berhasil mengamplifikasinya DNA dari hewan sapi dan babi dengan panjang fragmen yang berbeda-beda dalam campuran DNA (DNA mix) dari 2 jenis hewan ternak tersebut dalam satu reaksi sehingga terbentuk 2 pita DNA dengan panjang berbeda sesuai denga panjang fragmen masing-masing hewan. Dari hasil penelitian terhadap kontrol daging sapi dan babi menghasilkan dua fragmen yaitu sebesar 274 pb untuk sapi dan 389 pb untuk babi. Pengujian multipleks PCR pada sampel bakso menunjukan bakso yang diujikan kandungan DNA nya 100\% positif mengandung sapi dan $0 \%$ mengandung babi. Sedangkan pengujian pada produk sosis terdapat satu merk sosis yang menunjukan hasil ampifikasi DNA sebesar 398pb yang berarti produk tersebut positif mengandung babi.
\end{abstract}

Kata kunci: Bakso, sitokrom b, DNA, PCR, sosis 


\section{INTRODUCTION}

The role of animal protein especially meat, was quite important in order to achieve nutritional worthiness standards. Changes in consumption patterns as well as between people cause animal food needs as primary needs that must be met because it is proven can make the community intelligent, active and productive so that the increase in consumption of animal protein is expected to improve the quality of human resources.

Food safety of animal product certainly cannot be separated from attention. Food safety was define as the conditions and efforts needed to prevent food from possible biological, chemical, physical and other contaminants that can harm and endanger human health (Government Regulation No. 28/2004). The government has tried to protect consumers with a variety of laws and government regulations, but until now falsification of food products, especially processed meat products were still common. Mixing other kind of meats in processed meat products usually to reduced production costs. Many cases of fraud and contamination with the use of materials that are not suitable for consumption and not halal. Contamination of these materials can occur at an early or final stage of production and some was accidental. The problem arises if the mixing of meat product used the type of meat that may not be consumed by certain people related to religion and culture.

Detection and identification methods for meat and processed products continue to be developed as an effort to protect consumers and implement food labeling. Specific DNA amplification techniques for each animal type in food safety and halal can be used for verification, certification and monitoring. Some researchers have used the cytochrome $b$ (cyt b) gene to distinguish material from different types of animals. Gene cytochrome b (cyt b) was mitochondrial DNA which more numerous than the nucleus DNA and its eternal presence. So the use of this gene is expected to enable the success of PCR amplification with the availability of DNA was many times more than nucleus DNA and the extraction results sufficient to detect samples in small amounts. Specific primary use for pork has been carried out by several researchers in recent years (Fatimah 2013), (Hertanto et al. 2017), (Marlina et al. 2013), (Maryam et al. 2015), (Rahmawati et al. 2016), (Rohman et al. 2017), (Zulfahmi 2015). The genes most commonly used as markers of animal or meat types include cytochrome b (cyt b), $12 \mathrm{~S}$ and $16 \mathrm{~S}$ ribosomal RNA subunits and displacement loop (D-loop) regions. Aim of this study was to detect pork contamination in meat processed products in Pandeglang Banten using specific primers derived from cyt $b$ sequences in pigs using the PCR multiplex technique.

\section{MATERIALS AND METHODS}

\section{DNA Samples}

DNA samples in this study came from meat and meat processed products. The sample consisted of positive controls there was beef and pork, meat processed products in the form of 5 samples meatballs and 5 samples sausage products. All samples was collect from Pandeglang Regency using an accessible source population method then labeled and stored at freezer temperatures until DNA extraction was carried out.

\section{Primer}

Primers used for amplification of specific DNA fragments of beef and pork followed Matsunaga et al. (1999). The forward primers used for both types of meats are 5-GAC CTC CCA GCT CCA TCA AAC ATC TCA TCT TGA TGA AA-3 ‘. The reverse primary sequences used in the study was present in Table 1.

Table 1. Specific Primer Sequences of Gene Cyt b From Beef and Pork

\begin{tabular}{lll}
\hline Sample & \multicolumn{1}{c}{ Reverse (5' -3') } & $\begin{array}{c}\text { Amplification } \\
\text { Result }\end{array}$ \\
\hline Beef* & $\begin{array}{l}\text { CTA GAA AAG TGT AAG ACC } \\
\text { CGT AAT ATA AG }\end{array}$ & $274 \mathrm{bp}$ \\
Pork * & $\begin{array}{l}\text { GCT GAT AGT TTT GTG ATG ACC } \\
\text { GTA }\end{array}$ & $398 \mathrm{bp}$ \\
\hline
\end{tabular}

\section{Procedure}

\section{DNA Isolation and Extraction}

DNA isolation and extraction methods in this study came from fresh meat samples and meat processed products using a Rneasy mini kit 50 (QIAGEN).

\section{Testing of Total DNA}

Extracted DNA as qualitatively and quantitatively tested by spectrophotometer. DNA samples of $3 \mu 1$ was put into $1.5 \mathrm{~mL}$ eppendorf tubes plus $597 \mu \mathrm{L}$ distillate water. The TE solution (Tris EDTA) used as a blank in the same way as $3 \mu \mathrm{L}$ of TE solution plus distillate water, then put in a $1.5 \mathrm{~mL}$ eppendorf tube. The samples and blanks were spin down for 0.5 minutes, then tested using a spectrophotometer. Testing of DNA doom with UV spectrophotometers at wavelengths of $260 \mathrm{~nm}$ and $280 \mathrm{~nm}$. The extracted DNA concentration was calculated from A 260 times the diluent factor and the DNA absorption constant $(50 \mu \mathrm{g} / \mathrm{mL})$.

\section{Amplification of Specific DNA Fragments}

Amplification of the cyt b gene segment was carry out by the multiplex PCR method. DNA samples of $2 \mu \mathrm{L}$ were put into a $0.2 \mathrm{~mL}$ PCR tube, PCR components were added consisting of $10 \mathrm{pmol}$ forward primers, 5 pmol reverse primers, $200 \mathrm{~mL} \mathrm{dNTP} \mathrm{mix,} 1 \mathrm{mM} \mathrm{MgCl}$, and 0.5 units of $\mathrm{T} a q$ polymerase enzymes and the buffer. The amplification process was carried out on a GeneAmp® PCR System (Applied Biosystems TM) thermocycler with a temperature of $94{ }^{\circ} \mathrm{C}$ for 5 minutes, 30 cycles consisting of denaturation of $94{ }^{\circ} \mathrm{C}$ for 30 seconds, annealing $60{ }^{\circ} \mathrm{C}$ for 45 seconds, elongation $72{ }^{\circ} \mathrm{C}$ for 1 minute and Final elongation of $72{ }^{\circ} \mathrm{C}$ for 5 minutes. After the process was complete, the tube was taken and stored at room temperature or at $4{ }^{\circ} \mathrm{C}$ until it will be further analyzed.

\section{Electrophoresis and Visualization of PCR Products}

PCR products visualized in agarose gel $1.5 \%$ used 
electrophoresis techniques. The gel was made from 0.6 gram agarose and $30 \mathrm{ml}$ of heated buffer solution $(0.5 \times$ TBE). Agarose solution allowed cool slightly while stirring with a stirrer, then added $2.5 \mu \mathrm{L}$ ethidium bromide dye. 5 $\mu \mathrm{L}$ of PCR product were dissolved in $1 \mu \mathrm{L}$ loading dye. Electrophoresis was carried out for 40 minutes at a constant voltage of 100 volts or until the bromtimol blue dye reaches the bottom of the gel. After electrophoresis completed, the gel taken for UV photography.

\section{RESULTS AND DISCUSSION}

The quality and quantity of DNA in an organism can be determined by using a spectrophotometer. The principle of this tool was the irradiation of ultraviolet light absorbed by the nucleotides and proteins in solution. Ultraviolet irradiation by nucleotides was maximally achieved at 260 $\mathrm{nm}$ wavelength, whereas maximum ultraviolet irradiation by proteins is achieved at $280 \mathrm{~nm}$ wavelengths (Tenrilulo, Suryati, Parenrengi and Rosmiat 2017). Based on research that has been done on the level of purity and concentration of DNA from isolation, the data obtained are presented in Table 2.

Table 2. Purity and Concentration of DNA Solution in Beef, Pork, Meatballs and Sausage Samples Using UV-Vis Spectrophotometer

\begin{tabular}{lcc}
\hline Sample & Purity A260/A280 $(\mathrm{nm})$ & Concentration $(\mu \mathrm{g} / \mathrm{mL})$ \\
\hline Beef & 1.87 & 558.90 \\
Pork & 2.19 & 610.65 \\
Meatball 1 & 1.83 & 11.85 \\
Meatball 2 & 1.75 & 21.35 \\
Meatball 3 & 1.79 & 18.15 \\
Meatball 4 & 1.69 & 12.90 \\
Meatball 5 & 1.71 & 8.60 \\
Sausage 1 & 1.62 & 22.90 \\
Sausage 2 & 1.81 & 45.95 \\
Sausage 3 & 1.80 & 21.00 \\
Sausage 4 & 1.47 & 7.25 \\
Sausage 5 & 1.87 & 13.80 \\
\hline
\end{tabular}

The results of absorbance measurements at a wavelength of 260/280 nm was vary because it was depends on the source of the DNA obtained. DNA extracted from meat had a ratio of absorbance values in the range of 1.8 to 2.0 than DNA extracted from processed products. DNA molecules are said to be pure if the A / 280 ratio ratio of 280 is equal to 1.8-2.0 (Fatchiyah 2011). These results indicated the level of DNA purity from meat is higher than DNA derived from processed products. This is likely caused by the contamination of proteins and other mixtures used in processed products.

Very important to know how much DNA concentration was used in research. The concentration of extracted DNA was varied. This was due to the extracted samples coming from different sources there was meat and meatballs and sausage. According to the KapaBiosystem (2014) recommendation cited by Nugroho et al. (2017), the template DNA concentration needed for PCR activities ranged from $10-100 \mu \mathrm{g} / \mathrm{mL}$ whereas according to Maryam (2014) the optimal concentration in PCR amplification at 30 cycles to produce thick bands was a $50 \mu \mathrm{g} / \mathrm{mL}$ concentration both in beef comparison, pork, beef meatball samples and pork meatball samples. In this study showed that the concentration of DNA in beef and pork samples was very high, namely 558.90 and $610.65 \mu \mathrm{g} / \mathrm{mL}$, because the extracted sample was a fresh meat without any mixture material.

Concentration of DNA extracted from meatballs and sausage was relatively less because in extracted sample there was a mixture of other ingredients such as flour, spices and other ingredients that was not contain DNA. Beside that some treatments in making processed meatball and sausage products can cause difficulties during DNA isolation and extraction. Important stages that affect the difficulty of DNA isolation from meatballs and sausages were (1) mechanical processing including chopping and grinding meat on meatballs and sausages can cause changes in particle size, shape and composition of meat constituent proteins so that it affects the state of cells which contain DNA, (2) heating treatment with high temperature and pressure such as boiling in boiling water $\left(100^{\circ} \mathrm{C}\right)$ the process besides causing denatured protein also affects the stability of DNA, (3) mixing of additives in meatballs and sausages in the form of flour and spices the other.

Matsunaga et al. (1999) showed that DNA can be isolated from meat that has been heated at temperatures of $100{ }^{\circ} \mathrm{C}$ and $120^{\circ} \mathrm{C}$ for 30 minutes. Nuraini (2004) succeeded in isolating and amplifying DNA from body organs and processed meat products such as meatballs, sausages, corned beef, beef jerky and shredded, or it can be said that heating does not damage DNA (Nuraini 2004). Martín et al. (2007) succeeded in amplifying mitochondrial DNA in 12SrRNA regions in DNA samples of cat, dog and mouse meat heated at $120^{\circ} \mathrm{C}$ for 50 minutes, $110^{\circ} \mathrm{C}$ for 120 minutes and $133^{\circ} \mathrm{C}$ at $300 \mathrm{kPa}$ pressure for 20 minutes. According to Kesmen et al. (2007), DNA amplification was not influenced by adding a spicies or cooking proccess. Based on purity and concentration data extracted and isolated DNA this study as a whole is good and can be used for the amplification process

The used of the cyt $b$ gene had extensively carried out in research for the identification of types of meat (Di Pinto et al. 2005, Asensio 2007, Hsieh et al. 2007, Tanabe et al. 2007, and Lin et al. 2008). Besides using cyt b as a biological marker in species identification, 12S rRNA genes (Fajardo et al. 2006) and 16S rDNA (Rastogi et al. 2007) can be used, all of which are mitochondrial DNA genes.

The cyt $b$ DNA fragment amplification process used specific primers refers to Matsunaga et al. (1999), with the same forward primers used for all types of animals namely 5 '-GAC CTC CCA GCT CCA TCA AAC ATC TCA TGA TGA TGA AA-3', and reverse primer for cattle that was 5 "-CTA GAA AAG TGT AAG ACC CGT AAT ATA AG-3 "and pigs is 5"-GCT GAT AGT AGA TTT GTG ATG ACC 
GTA-3 “. The results of the amplification of cyt b fragments in meatball samples in determining the presence or absence of pig DNA contamination was presented in Figure 1.

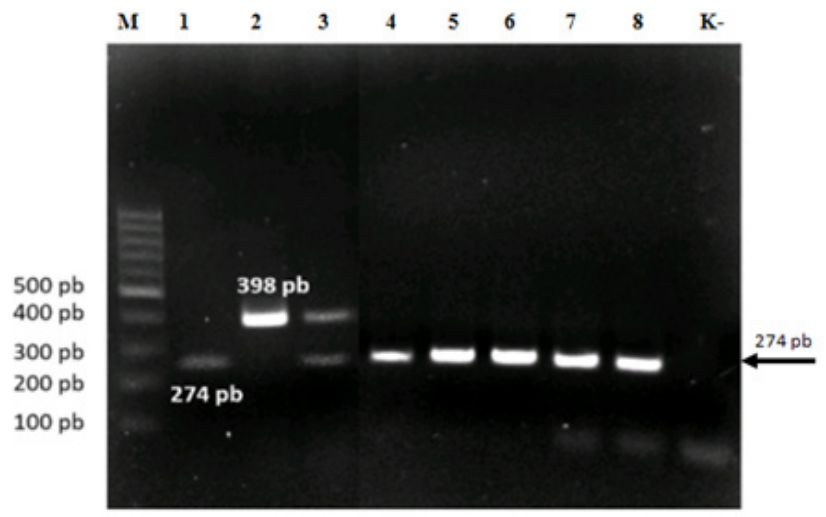

Figure 1. Visualization of results of amplification of DNA cyt $b$ fragments of meatball samples on agarose gel 1.5\%, (M) Marker $100 \mathrm{bp}$, beef control sample (1), pork control (2), beef and pork mixture control (3), meatball samples (4 -8) and K-negative controls in the form (water)

From Figure 1 showed that the results of cyt $b$ gene amplification in agarose gel produce two different fragments there were $274 \mathrm{bp}$ DNA fragments of beef and $398 \mathrm{bp}$ DNA fragments of pork this was according to Primasari (2011) and Irine (2013) who succeeded in amplification of beef and pork fragments of 274 bp and 398 bp respectively. DNA analysis results showed that for all meatballs samples $100 \%$ positive contained beef DNA and negative contained pork DNA. This indicates that beef meatball samples in the Pandeglang was safe for consumption and there was no pork DNA contamination. While the identification analysis of sausage products can be seen in Figure 2.

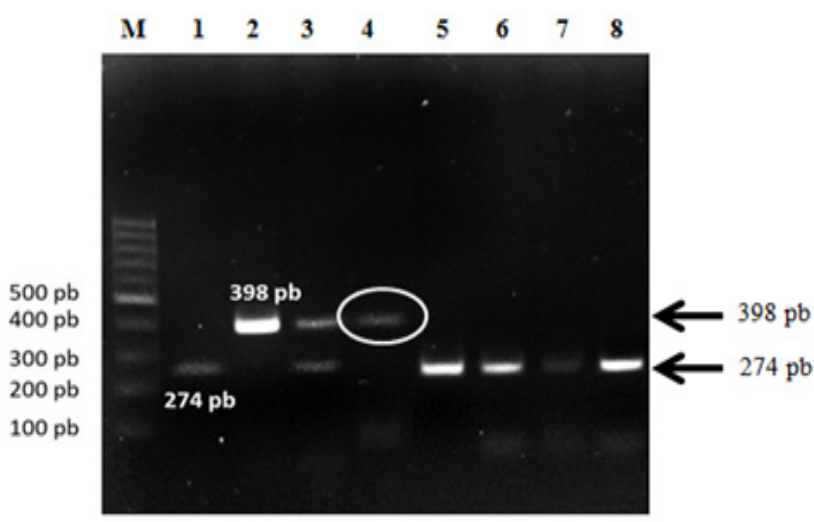

Figure 2. Visualization of the results of amplification of DNA cyt $b$ sausage samples on agarose gel1.5\%, (M) Marker 100 bp, beef control sample (1), pork control (2), beef and pork mix control (3), sausage sample (4-8)
Based on Figure 2. showed that the amplification of cyt b genes of beef and pork in sausage samples was successfully proven by visualization on agarose gels $(1.5 \%)$ where DNA bands were formed in all sausage samples analyzed. The results of the analysis showed that there was sausage product contained pork DNA where 398 bp of fragments were seen in the product test, namely sausage sample no. 4 so that it was confirmed to be positive containing pork DNA. While the results of cyt $b$ gene amplification of product samples number $5,6,7$, and 8 produce DNA bands with fragments of $274 \mathrm{bp}$ which indicate that the sausage product sausage was $100 \%$ positive contain beef DNA. The results of this study indicated that meat processed products sausages in Pandeglang Regency was not safe from contamination of pork DNA even though the sausage samples used in this study at packaging printed out MUI halal label and distribution permit number issued by BPOM.

Fontanesi et al. (2008) and Langen et al. (2010) detected pork based on the sex of pigs in the market. They found that pork that was marketed both fresh and processed could be identified and could even be known whether the pig was male or female. Detection method with specific primers showed positive results in pigs and did not amplify the same genes from other types of animals namely cows, chickens, turkeys and several types of microorganism that often contaminate meat.

Kesmen et al. (2007) used species-specific primers to detect meat species in sausage products with a variety of meat mixtures (horses, cows, donkeys and pigs) and showed results that could be detected up to a level of $1 \%$ by producing different amplicons. Specific primers design was obtained from ATPase8 (ATP synthase subunit 8), ATPase6 (ATP synthase subunit 6), ND2 = NADH (dehydrogenase subunits 2) and ND5 = NADH (dehydrogenase subunit 5 ). The results of research to identify species with specific promers have also been developed by Martin et al. (2007) which was able to detect the presence of beef, goat and lamb up to the level of $1.0 \%$ in a mixture of flour and other vegetable materials. The study also explained that cooking to temperatures of $120^{\circ} \mathrm{C}$ for up to 50 minutes could still be used for PCR reactions with specific primers designed from the $12 \mathrm{~S}$ rRNA gene.

Detection and identification techniques of animal origin, especially in food products, very important because they was related to health, economy and religion. Safe and halal meat was a major concern, especially for the majority Muslim community of Indonesia. Detection and identification methods of meat types usually used protein analysis, but this method had a weakness it was only can be done in fresh meat sample, required a large sample and very low accuracy when done on processed meat.

The used of multiplex PCR and the superiority of cyt $b$ gene variation in this study proved to be successful in detected and identified the type or source of meat quickly, precisely and accurately. The primers was used one forward primer and 2 reverse primers arranged in a specific area in each animal. The specificity of the cyt $b$ gene was proven by the amplification of DNA from beef and pork with different fragment lengths and the DNA mix of the 2 
types of livestock can be amplified in one reaction so that 2 DNA bands formed with different lengths according to the fragment length each animal. So the advantages of multiplex PCR techniques that can save time and cost of analysis because to detected samples with different DNA sources can be done in one reaction so this methode can be more efficient.

\section{CONCLUSION}

Amplification of the gene cyt $\mathrm{b}$ in beef, pork and meat processed products resulted in two different DNA fragments there was $274 \mathrm{bp}$ for beef DNA and $398 \mathrm{bp}$ for pork. Other types contamination of meat in processed meat products could still analyzed for DNA used multiplex PCR technique even though the processed meat products had undergone mechanical treatment, temperature treatment and also the addition of other food additive materials. The results of DNA analysis of processed meat products in the Pandenglang showed that for five meatball samples that observed was all samples negative containing pork DNA and $100 \%$ contained beef DNA. As for the sausage product tested, it was found one sample of five tested samples proved to be positive containing pork DNA, which was shown from the DNA band resulted from electrophoresis visualization on agarose gel 1.5. this study indicated that meat processed products sausages in Pandeglang Regency was not safe yet from contamination of pork DNA.

\section{REFERENCES}

Asensio, G. L. 2007. PCR-based methods for fi sh and fi shery product authentication. Food Control \& Technology. 18:558-566.

Di Pinto, A., Forte, V.T., Conversano, M.C. \& Tantillo, G.M. 2005. Duplex polymerase chain reaction for detection of pork meat in horse meat fresh sausages from Italian retail sources. Food Control. 16: 391-394.

Fajardo, V., Gonzales, I., Lopez-Calleja, I., Martin, I., Hernández, P.E., Garcia, T. \& Martin, R. 2006. PCR-RFLP authentication of meats from red deer (Cervus elaphus), fallow deer (Dama dama), roe deer (Capreolus capreolus), cattle (Bos taurus), sheep (Ovis aries), and goat (Capra hircus). Journal of Agricultural and Food Chemistry 54: 1144-1150.

Fatchiyah,. Aruminingtyas, E.L., Widyarti, S., \& Rahayu, S. 2011. Molecular Biology-Basic Principles of Analysis. Erlangga, Malang.

Fatimah, S. 2013. Detection of Pork Contamination in Chicken Meatballs Mix with Real-Time PCR and FTIR Spectrophotometry, [Thesis], Faculty of Pharmacy, Gadjah Mada University, Yogyakarta.

Fontanesi, L., Scotti, E. \& Russo, V. 2008. Differences of the Porcine Amelogenin X and Y chromosome genes (AMELX and AMELY) and their application for sex determination in pigs. Molecular Reproduction and Deve

Fatmawati, D.A., Wirajana, N., \& Yowani, S.C. 2015. Comparison of DNA Quality using the Original Boom and Modified Boom Methods on Mycobacterium tuberculosis Isolates 151. CHEMICAL, vol. q, pp. 4145. lopment 75: 1662-1668..

Hertanto, B.S., Fitra, R.A., Kartikasari, L.R., \& Cahyadi, M. 2017. Authentication of Raw Chicken Mear from Pork Contamination using Gene CYT-B with Duplex-Polymerase Chain Reaction Analysis, Buletin Peternakan, vol. 41, pp. 113-118

Hsieh, H.S., Tuu-jyi, C. \& Deng-Fwu, H. 2007. Using the PCR-RFLP method to identify the species of different processed products of billfi sh meats. Food Control 18: 369-374.

Kesmen Z, Sahin F, \& Yetim H. 2007. PCR assay for the identification of animal species in cooked sausages. Meat Sci 77:649-653.

Langen, M., Peters, U., Körner, U., Gissel, C., Stanislawski, D. \&Klein, G. 2010. Detection of male pork tissue in meat and meat products by PCR. Meat Science 86 : 821 824.

Lin, W. \& Deng-Fwu, H. (2008). Application of speciesspecific PCR the identification of dried bonito product (Katsuobushi). Food Chemistry 106: 390396.6.

Marlina, Mutalib, S.A., Islami, Sari, H.K., \& Fitria, A. 2013. Development of PCR and Southern Hybridization Methods for the Detection of Swine Genes in Capsules. Pros. Semin. Nas. Perkemb. Terkini Sains Farm. Dan Klin. III, pp. 116-121

Martín et al. 2007. Technical note: detection of cat, dog, and rat or mouse tissues in food and animal feed using species-specific polymerase chain reaction. J Anim Sci 85:2734-2739.

Martin, I., Garcı'a, T., Fajardo, V., Pez-Calleja, I., Herna'ndez, P.E., Gonza'lez, I. \& Martı'n, R. 2007. Species-specifi c PCR for the identification of ruminant species in feedstuffs. Meat Science 75: 120-127.)

Maryam, S. 2014. Analisis Cemaran DNA Babi Pada Dendeng menggunakan primer mitokondria D-Loop686 dan gen cyt b dengan menggunakan Real time polymerase chain reaction (real time PCR), [Tesis], Fakultas Farmasi. Universitas Gadjah Mada, Yogyakarta.

Maryam, S., Sismindari, Raharjo, T.J., Sudjadi, \& Rohman, A. 2015. Determination of Porcine Contamination in Laboratory Prepared dendeng Using Mitochondrial D-Loop686 and cyt $b$ Gene Primers by Real Time Polymerase Chain Reaction, International Journal of Food Properties, vol.19, no. 11, pp. 187-195. 2017,https://doi.org/10.1080/10942912.2015.1020434

Matsunaga T et al. 1999. A quick and simple method for the identification of meat species. Meat Sci 51:143148.)

Nugroho, K., Terryana, R.T., \& Lestari, P. 2017. Chili DNA Extraction Method (Capsicum annuum L.) using Buffer CTAB modification (Cethyl Trimethyl Ammonium Bromide) tanpa Nitrogen Cair, Scripta Biologi, vol. 4, no. 2, pp. 91-94

Nuraini H. 2004. Development of the Porcine Repetitive Element (PRE-1) sequence as a molecular marker for 
detecting pork material in processed meat products. [dissertation]. Bogor: Postgraduate School, Bogor Agricultural University

PP RI. 2004. Republic of Indonesia Government Regulation No. 28/2004 concerning Food Safety, Quality and Nutrition. Jakarta.

Primasari A. 2011. Sensitivity of the cytochrome b * cyt b gene (as a specific mark on the genus Rattus and Mus to ensure food safety of meat origin products. [thesis]. Bogor: Postgraduate School, Bogor Agricultural Institute.

Rastogi, G., Mahesh S. Dharne, Sandeep W., Ashutosh K., M.S. Patole dan Yogesh S.S. 2007. Species identifi cation and authentication of tissues of animal origin mitochondrial and nuclear markers. Meat Science 76: 666-674.

Rahmawati, Sisimindari, Raharjo, T.J., Sudjadi, \& Rohman, A. 2016. Analysis of Pork Contamination in Abon using Mitochondrial D-Loop 22 primer Using Real-Time Polymerase Chain Reaction Method, International Food Research Journal, vol. 23, pp. 370-374.
Rohman, A., Himawati, A., Triyana, K., Sismindari, \& Fatimah, S. 2017. 'Identification of Pork in Beef Meatballs using Fourier Transform Infrared Spectrophotometry and Real-time Polymerase Chain Reaction, International Journal of Food Properties, vol. 20, pp. 654-661.

Tanabe, S., Eiji, M., Akemi, M. \& Kazuhiro, M. 2007. PCR method of detecting pork in foods for verifying allergen labeling and for identifying hidden pork ingredient in processed foods. Biosci. Biotechnol. Biochem 71: 1-5.

Tataurov AV, You Y, \& Owczarzy R. 2008. Predicting ultraviolet spectrum of single stranded and double stranded deoxyribonucleic acids. Biophys Chem 133 (1-3):66-70.

Tenriulo, A., Suryati, E., Parenrengi, A., \& Rosmiati. 2001. Ekstraksi DNA Rumput Laut Rappaphycus alvarezil dengan metode Fenol Kloroform', Marina Chimica Acta, vol. 2, no. 2, pp. 6-10

Zulfahmi. 2015. Detection of Pig Contaminants in Food Products Using Molecular DNA Technology, Kutubkhanah: J. Researchers. Sauce. Diversity, vol. 18 , no. $1, \mathrm{pp}$. 